\title{
GIS BASED TEMPORAL ANALYSIS OF LAND USE PATTERN AND ITS IMPACT - PROPOSED GURGAON MANESAR URBAN COMPLEX
}

\author{
MANUJ DEV ${ }^{* 1}$, DR. S. M. VEERABHADRAPPA ${ }^{2} \&$ MANAS KUMAR JHA ${ }^{3}$ \\ ${ }^{I}$ Research Scholar, Amity Institute of Geoinformatics and Remote Sensing (AIGIRS), Amity University, Noida, Uttar Pradesh, \\ India \\ ${ }^{2}$ Professor, Amity Institute of Geoinformatics and Remote Sensing (AIGIRS), Amity University, Noida, Uttar Pradesh, India \\ ${ }^{3}$ Senior Project Manager (Mapping), Hexagon Geosystem, Plot No 121, Phase I, Udyog Vihar, Sector 20, Gurugram, Haryana, \\ India
}

\begin{abstract}
Objectives: The objective of this study is to analyse the rapidly changing land use pattern for past several years around proposed Gurgaon Manesar urban complex and its socioeconomic impact on the residents. Material and Methods: GIS based temporal analysis of land use pattern was done using Landsat satellite Imagery for the year 1987, 2011, 2014 and 2019. Georeferencing of the satellite imagery was done using Ground control Point in the first phase and then Land use pattern was digitised using Arc GIS software in the second phase. The distinct land use for past years was then analysed using population and agriculture data to understand the socio-economic impact. Findings: The infrastructure projects and Immigrants Population has resulted in an increase of settlement area which has increased from $2 \%$ in the year1987 to $15 \%$ in 2011 of total Manesar tehsil area which grows up to $21 \%$ in 2014 and currently occupies $26 \%$ of the total area. The increasing settlements area has direct impact on the count of household which has increased from 13817 in 2001 to 44074 in 2011 and is expected to grow up to 57476 by the year 2021. Result suggests that Manesar Township as well as other villages across the tehsil is going to be spatially expanded soon. Increasing population density will result in high water demand. Currently, the dependency is on groundwater which may worsen in the coming days as Central Ground Water Board (CGWB) has reported the depletion of the water table by 1-1.2 meter every year. There were also various haphazard developments, construction of real estate buildings not meeting the criteria of a planned city. The lesson learnt from the failure in planning the Gurgaon city must be taken into consideration and Coordination among various government organizations must be balanced for the speedy resolution of open issues and faster decision-making. This may lead to a path towards strengthening e-governance. Novelty/Applications: The guidelines to obtain various permissions across the government machinery must be updated to accommodate the various new planning strategies. Public-private partnership may be the best approach where faster development may occur with world-class amenities, which is currently lacking to a greater extent.

KEYWORDS: GIS; Urban Planning; Remote Sensing; Land Use; Temporal Analysis
\end{abstract}

Received: Jun 09, 2020; Accepted: Jun 29, 2020; Published: Aug 06, 2020; Paper Id.: IJMPERDJUN2020656

\section{INTRODUCTION}

Ancient India has witnessed the River Valley civilization where society with large settlements flourished using river water [1] as a prime source for drinking and agriculture. In parallel with that, the food, fodder, and fuel wood concept for limited exploitation of natural resources kept the ecosystem sustainable, intact, and healthy. Currently rapidly increasing population has shifted the pattern of settlements near to the industrial area or existing urban 
center, which is now identified as alternate sources of livelihood other than agriculture. A Report published by the UN Department of Economic and Social Affairs (UNDESA), suggests that currently, 55\% of the world population lives in urban areas. This is expected to grow to $68 \%$ by 2050 . The report also suggests that Delhi will become the most populated city and that too in less than 10 years. The population of Delhi's urban agglomeration will reach 3.7 crores in 2028 against Tokyo's 3.6 crores. The National Capital Region is the world's largest urban agglomeration with a population of more than 46 Million and comprises of NCT of Delhi, Thirteen Districts of Haryana [3], and two districts of Rajasthan and twenty districts of Uttar Pradesh.

The Increasing population density in Delhi, an urban agglomeration, and haphazard development in the NCR region necessitate the need toward the development of systematic and planned urban areas for residential, commercial as well as industrial purposes. The Government of Haryana has planned for the development of a new urban complex adjacent to Gurugram in the National Capital Region for sustainable urban development [2]. This new city will be developed in a public-private partnership (PPP) model, with proposed expansion spread across 50,000 hectares. The city will be located south of Delhi and will share boundaries with the Gurgaon-Manesar [1] urban area to the North and the Aravalli hills to the North-East. It will be connected to the neighboring urban centers through national and state highways, the Kundli-Manesar-Palwal (KMP) Expressway [1], and another major district road -Network. Today, Manesar [3] is facing the problem of unequal distribution of land use and the situation has worsened exponentially in the recent past. Our study has analysed the increasing population, rapid urbanisation [4] in the Manesar vicinity, and change in land use pattern of the proposed urban complex using temporal analysis of satellite imagery [5] from the year 1987 till 2019.

The Government initiative of smart city and housing for all in Delhi agglomeration area results in the rapid growth of real estate across the NCR region. Upcoming infrastructure projects and transportation facility makes the NCR region a viable option for residential, commercial as well as industrial development. The Government of Haryana [7] has made a similar attempt by initiating a concept of a planned city in Manesar [4], which is next to the existing Millennium city Gurugram. Manesar [4] used to be a sleepy village until the early '90s has now emerged as the fastest-growing Industrial town in Haryana [7]. It is a tehsil in District Gurugram and part of ahirwal region. Some of the major industries include Samsung telecommunications, Hero Motors Ltd., Honda Motorcycle \& scooters India, Mitsubishi Electricals, HCL, etc. The area has seen many changes in the land use-landcover [6] in the past couple of years. It is not only the Industries but also a lot of urbanization with many private builders jumping in to create housing societies. This fast growth of the NCR has adversely contributed to the development process due to various issues.

\section{LOCATION OF STUDY AREA}

Manesar (Lat $28.354285^{\circ}$, Long $76.939820^{\circ}$ ) is one among the five Tehsil of Gurugram district and a fast-growing industrial town next to National Highway 8. The nearest railway station is Ghari Harsaru (GHH), Patli, and Taj Nagar. The study area (Figure 1) spread over around 178 sq.km along the Manesar tehsil of Haryana [7] and part of the proposed Gurgaon - Manesar Urban complex. The area of interest extends [3] in the north to the Gurugram Township (28.459316 , $77.026509^{\circ}$ ) and extends to the Rewari railway line in the west. In the south extends until the Bilaspur Road across Tauru to Sohna $\left(28.248466^{\circ}, 77.063667^{\circ}\right)$ village. The climate of the study area can be classified as Tropical Steppe, Semi-Arid, and Hot which is mainly characterized by the extreme dryness of the air except during monsoon months, intensely hot summers, and cold winters. During three months of southwest monsoon from the last week of June to September, the moist air of oceanic origin penetrates the area and causes high humidity, cloudiness, and monsoon rainfall. 

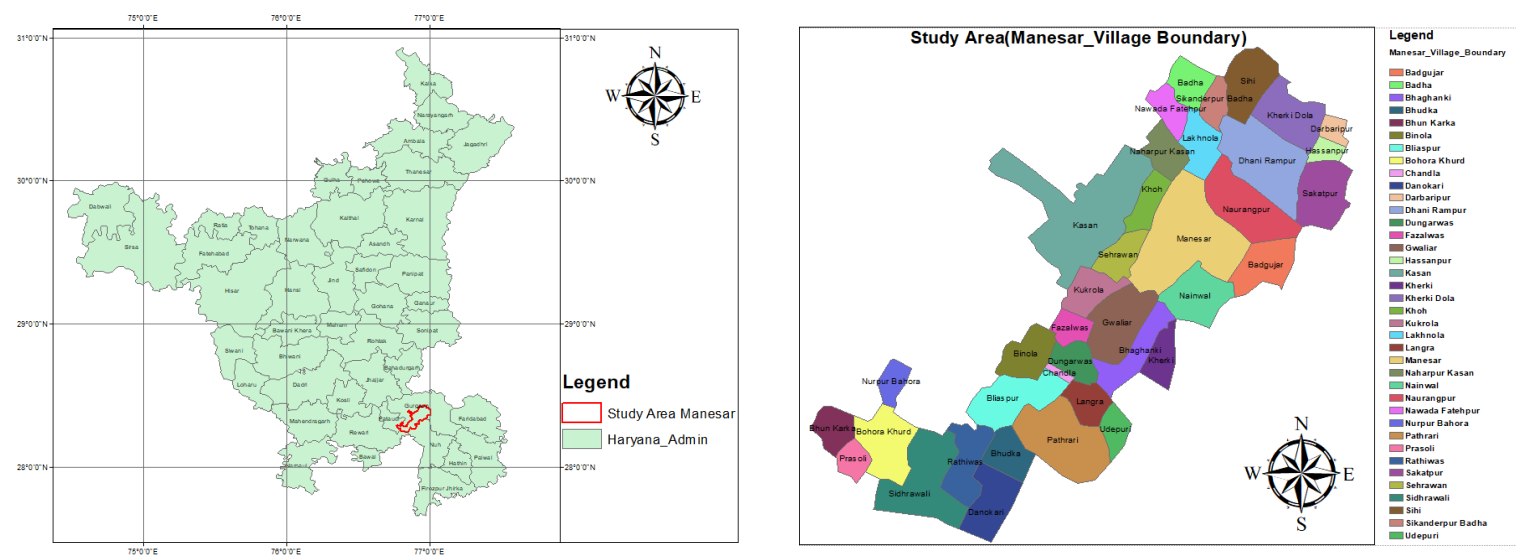

Figure 1: Location of Study across the Administrative Boundary of Haryana.

\section{SELECTION OF METHODOLOGY}

Rapid Urbanization of a certain area has many indicators such as changing crop patterns, change in land-use, land-cover, densification of the population [10], establishment of industry across a certain geographical region. Various studies suggest that the urbanisation of an area [7] facilitates the increasing economic aspects of the area thus attract more migrants to witness the population [10] densification. The Study of land use [6] and the land cover pattern is one of the Geospatial aspects where change detection of the geographical area can be done and analysed further using satellite imagery of past years [1]. Here identifying the change in land use and monitoring the pattern of such disparity indicates a trend towards the urbanisation of the area [7]. The selection of the methodology was done considering the above aspects where various spatial, as well as non-spatial data were collected for temporal analysis.

\section{SATELLITE DATA USED}

Available Landsat Satellite Imagery [6] of the study area was download from the USGS site [1] for the study purposes. Imagery for years 1987, 2011, 2014, and 2019 was available on USGS explorer, imagery was downloaded and used after required processing. The specification of the imagery was as below in Table 1;

Table 1: Imagery used and their Specification

\begin{tabular}{|c|c|c|}
\hline Year & Resolution & \multicolumn{1}{|c|}{ Specification } \\
\hline 1987 & 28 Meter Resolution & Landsat-5 with 5 Band \\
\hline 2011 & 30 Meter Resolution & Landsat-5 with 5 Bands, Acquisition Date 22nd Oct 2011 \\
\hline 2014 & 30 Meter Resolution & Landsat-8 with 11 Band, Acquisition Date 10 Dec 2014 \\
\hline 2019 & 30 Meter Resolution & Landsat-8 with 11 Band, Acquisition Date 29 Jan 2019 \\
\hline
\end{tabular}

The downloaded image was of multiple bands pan imagery and hence all band was merged by using ERDAS imagine software and converted into a multispectral image. Here for RGB band 4, 3, and 2 were used (Figure $2-5$ ). 


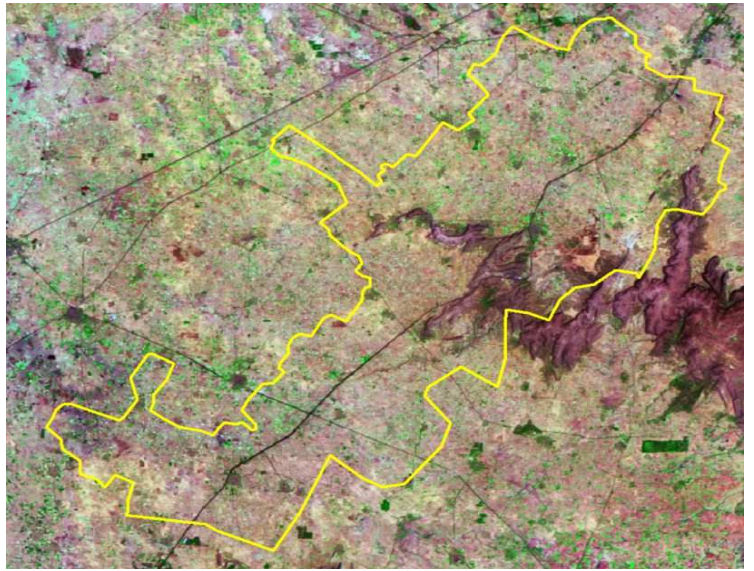

Figure2: Year -1987 (Band 1, 2, 3).

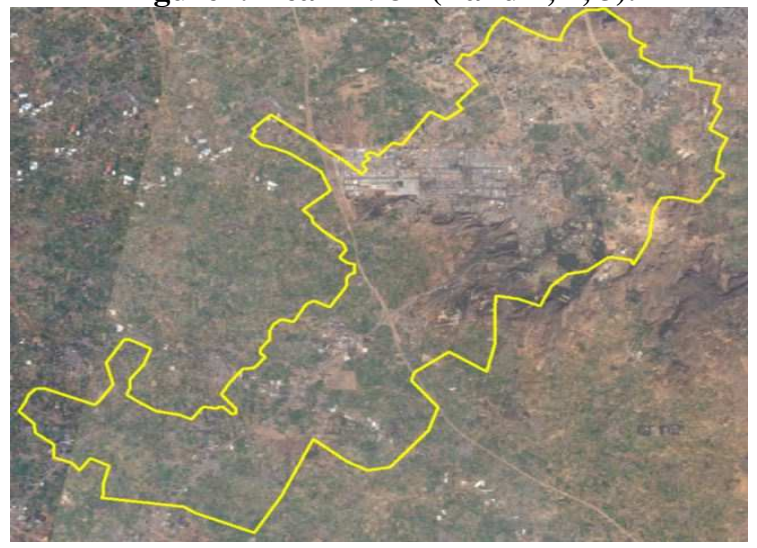

Figure 4: Year 2014 (Band 4, 3, 2).

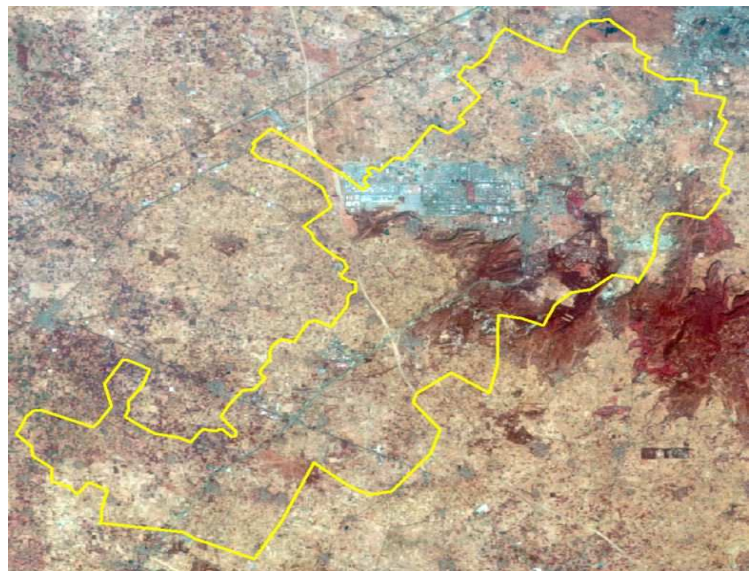

Figure 3: Year 2011 (Band 4, 3, 2).

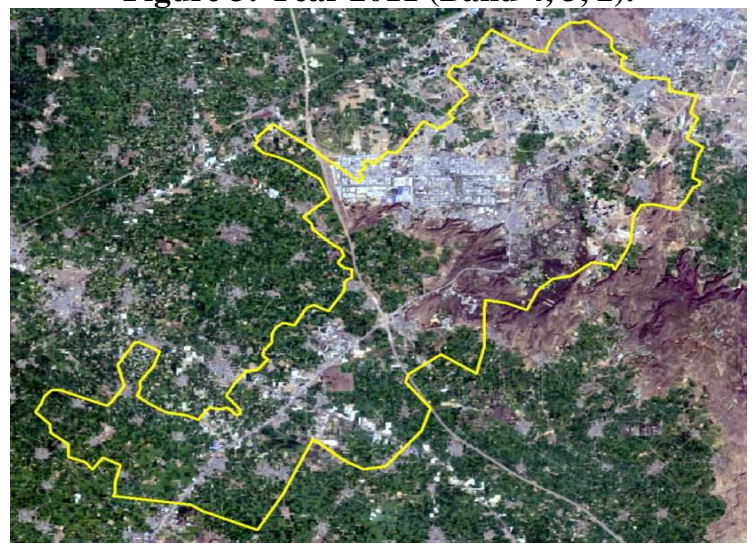

Figure 5: Year 2019 (Band 4, 3, 2).

\section{PREPARATION OF LAND USE LAND COVER}

For the preparation of land use, land cover map Arc GIS 10.2.1 was used. Here to understand the changing land use [6] pattern of past years, the following features were digitized on satellite imagery based on manual interpretation (Table 2);

Table 2: Features for Land use Classification

\begin{tabular}{|c|l|l|}
\hline S.NO & \multicolumn{1}{|c|}{ Features } & \multicolumn{1}{c|}{ Remarks } \\
\hline 1 & Settlement & Clustered, uncluttered building across the villages, town in study area \\
\hline 2 & Construction Site & Site where development work was found in progress across the years \\
\hline 3 & Cultivation & Agricultural farm land \\
\hline 4 & Dense vegetation & Forest or agricultural forest area \\
\hline 5 & Industrial_Area & Defined location as industries by Government across the study area \\
\hline 6 & Rock Area & Mountainous region \\
\hline 7 & Recreational Area & Tourist place and public/private area identified for recreational purposes \\
\hline 8 & Road & All transportation network covered under road category \\
\hline 9 & Water & All identified water body across the study area \\
\hline
\end{tabular}

\section{RESULTS AND DISCUSSIONS}

To understand the temporal changes in land use, pattern, and its impact on the 36 villages across the Manesar tehsil [5], the feature-wise area statistics were analysed (Figure 6 -9). The increasing trend of construction area [7], as well as the industrial area (Figure $10-11$ ), has a proportionate impact on the settlements, which was also analysed as increasing in past years. Transportation network has increased considerably over the past and almost doubled in the last 10 years. The increasing trend of manmade features has been associated with the shift in crop pattern where land used for cultivation has 
reduced considerably. Developed transportation network [2] helps the connectivity of the nearby markets with ease, which results in a change in cultivation from cereals to vegetables and fruits. However, the study suggests that agriculture products will be reduced further in the coming days due to land acquisition by governments and the development of urban complex.
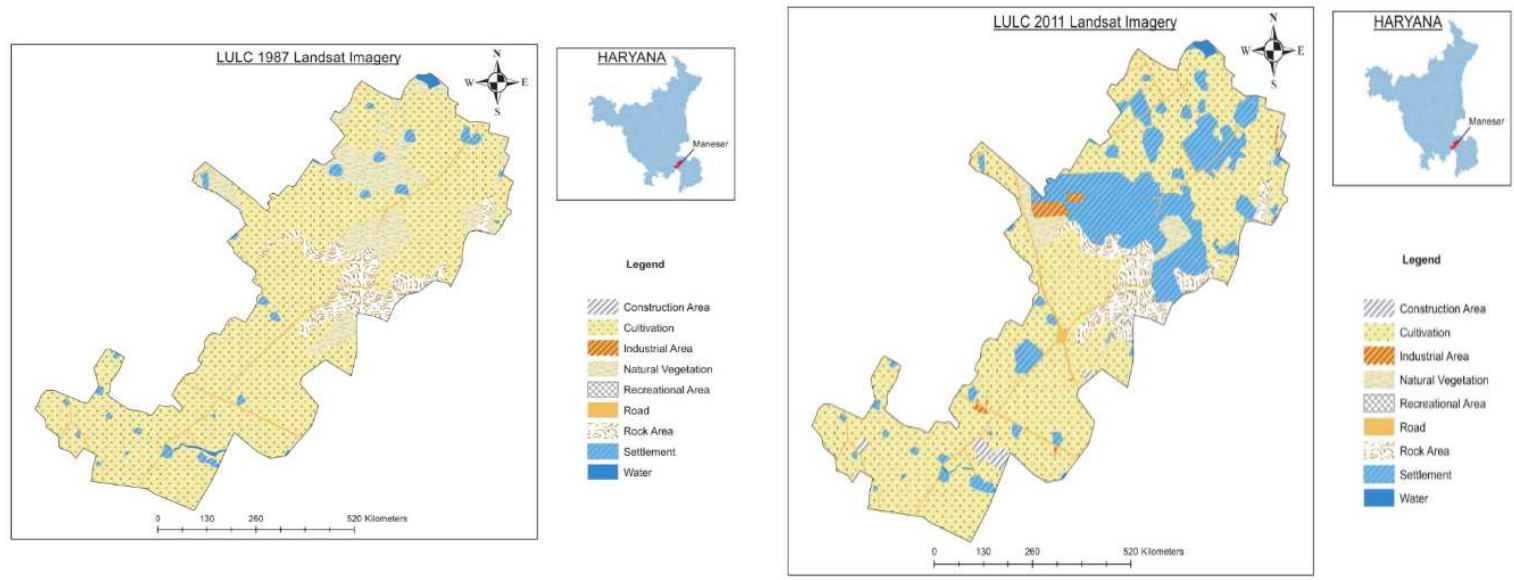

Figure 6: LULC Map for Year 1987.
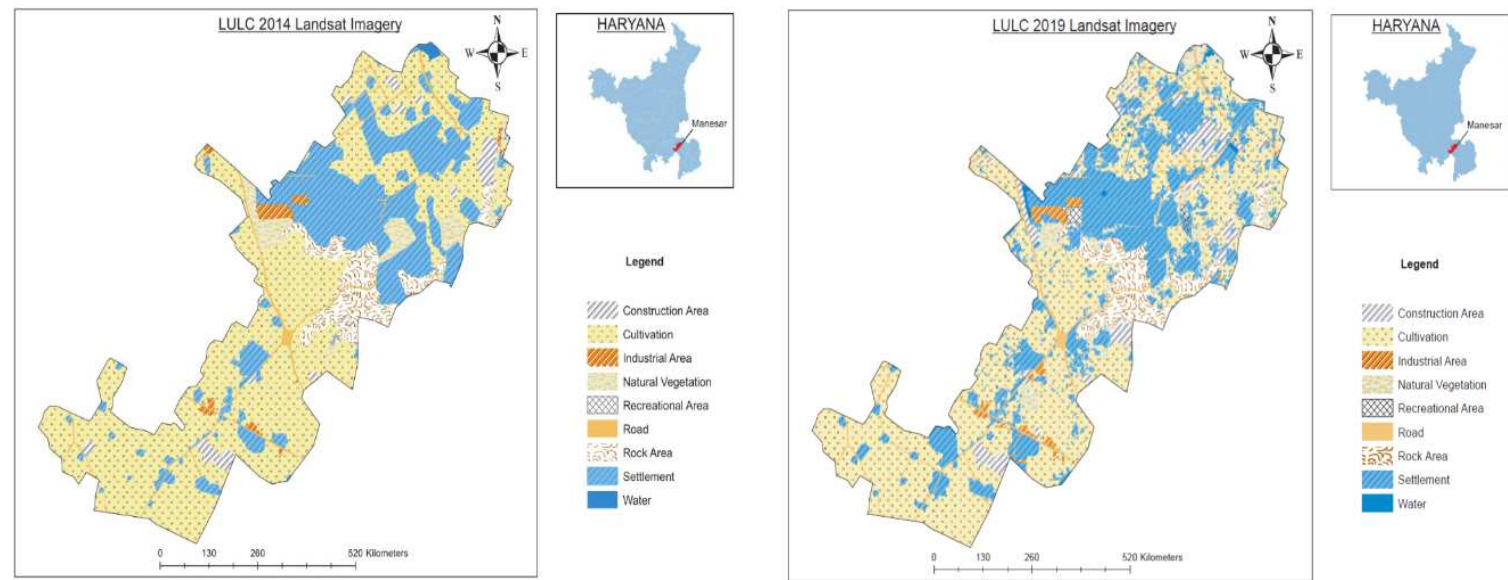

Figure 8: LULC Map for Year 2014.

Figure 9: LULC Map for Year 2019.

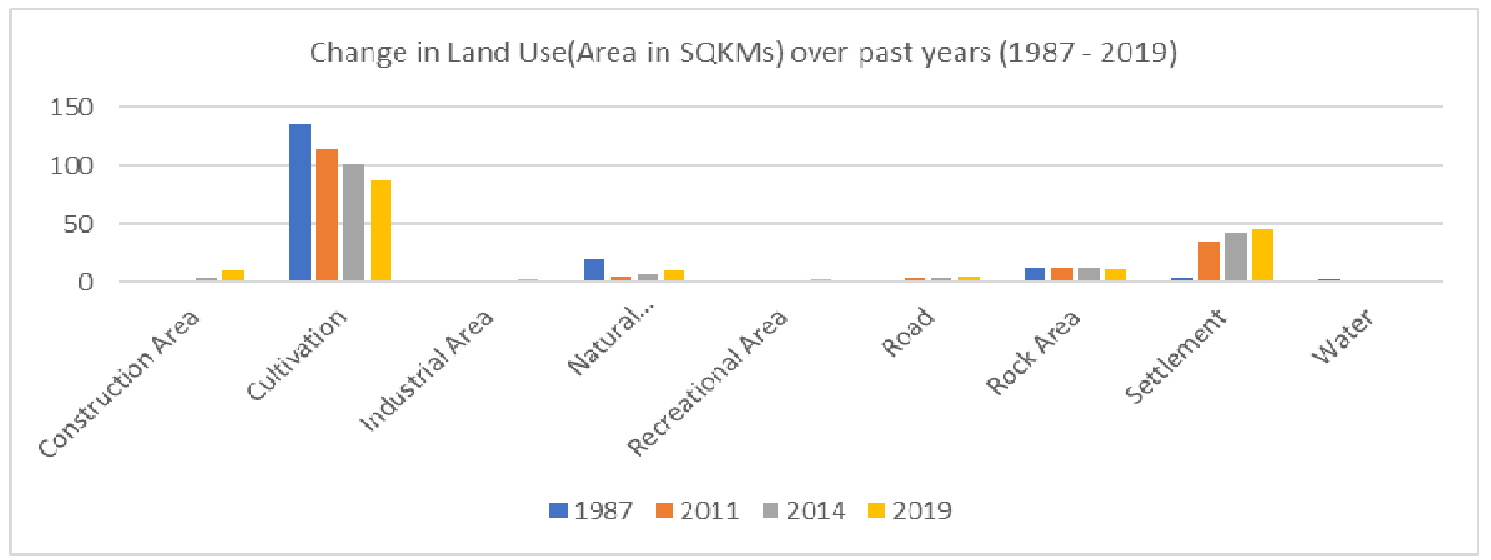

Figure 10: Graphical Representation of Features used for Land Use Classification Over Past Years. 


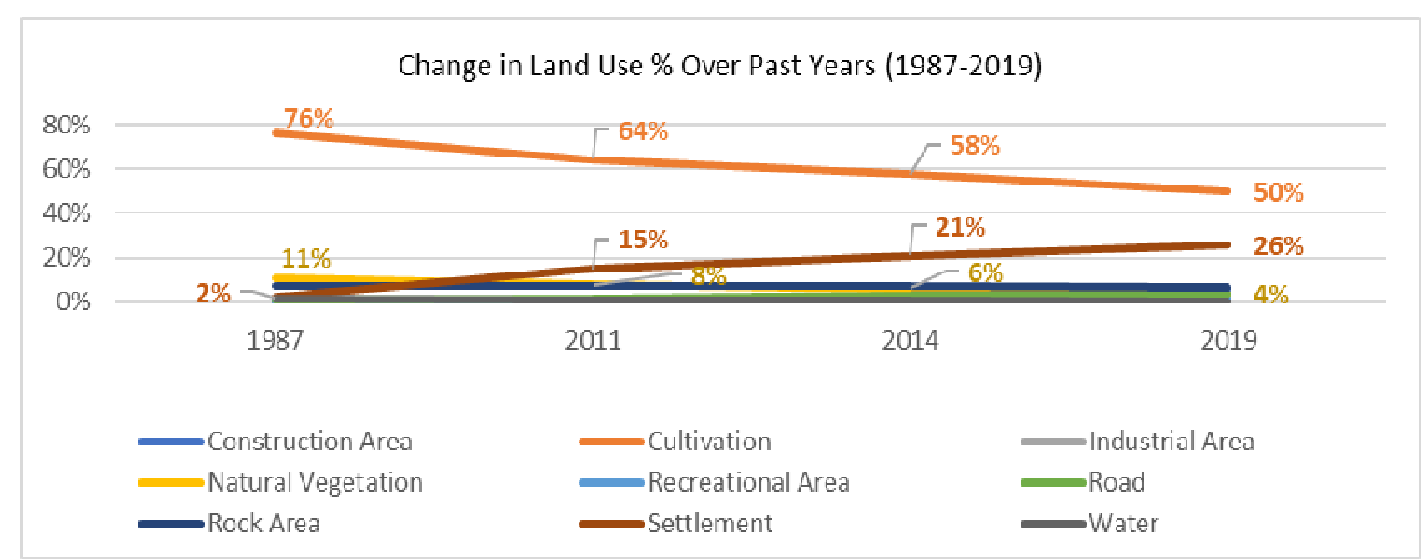

Figure 11: Graphical Representation of Features used for Land Use Classification Over Past Years.

\section{Population and Settlements}

Increasing infrastructure projects in the study area attract immigrants and thus results in rapidly increasing urban settlements and the human population. As per Census 2011, the Manesar Tehsil [4] comprises of 34 Villages having a population of 116,606 with 440, 77 households which have changed considerably in past years. If we calculate the increasing past population [10] using the "Geometric Growth Method" (Figure 12) the projected population of the 34 villages along Manesar tehsil [5] will be around 152064 by end of the year 2021. This method suggests an annual growth rate of the population by $3.2 \%$ whereas decadal growth of $39.7 \%$.

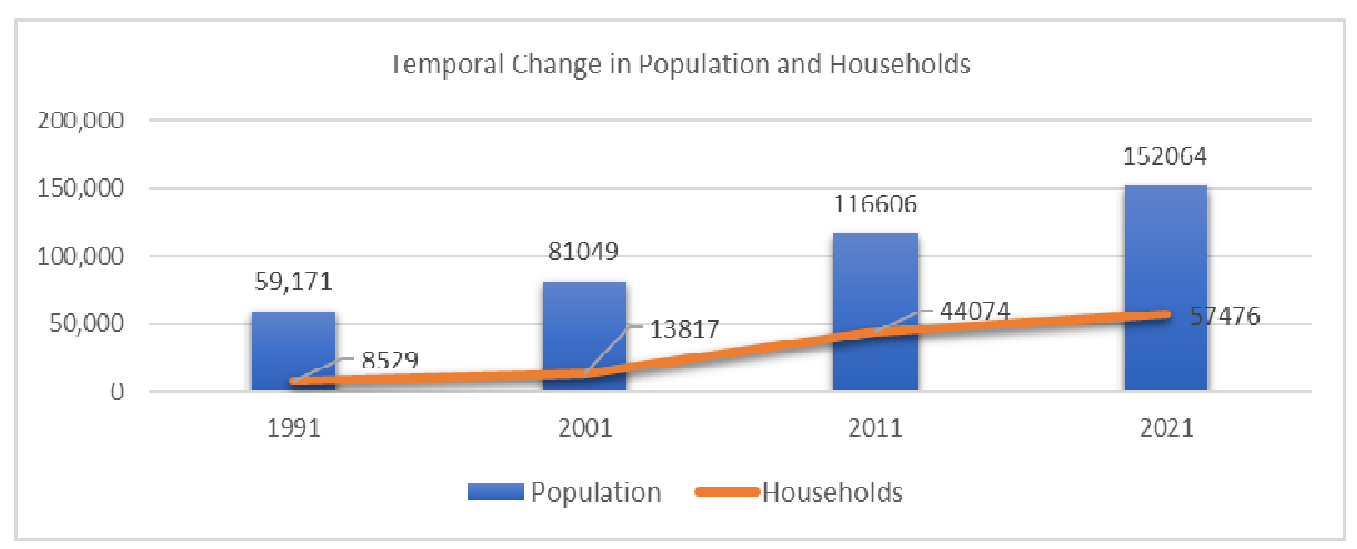

Figure 12: Census data of Population and Households (1991-2011) and forecasted Population for 2021.

Infrastructure projects and Immigrants Population [10] has results in the increase of settlement area which has increased from 2\% (1987) to 15\% (2011) of total Manesar tehsil area (Table 3) which grows up to 21\% (2014) and currently occupied $26 \%$ of the total area. The Increasing settlements area (Figure $10-11$ ) has a direct impact on the count of households which has increased from 13817 (2001) to 44074(2011) and expected to grow up to 57476 by 2021. 
Table 3: Percentage Proportion of Features used for Land Use Classification Over Past Years

\begin{tabular}{|c|c|c|c|c|c|c|c|c|}
\hline & \multicolumn{4}{|c|}{ Area Sq.km } & \multicolumn{4}{c|}{ Area \% } \\
\hline Feature & $\mathbf{1 9 8 7}$ & $\mathbf{2 0 1 1}$ & $\mathbf{2 0 1 4}$ & $\mathbf{2 0 1 9}$ & $\mathbf{1 9 8 7}$ & $\mathbf{2 0 1 1}$ & $\mathbf{2 0 1 4}$ & $\mathbf{2 0 1 9}$ \\
\hline Construction Area & 0 & 2 & 4 & 10 & $0 \%$ & $1 \%$ & $2 \%$ & $6 \%$ \\
\hline Cultivation & 135 & 114 & 102 & 88 & $76 \%$ & $64 \%$ & $58 \%$ & $50 \%$ \\
\hline Industrial Area & 0 & 2 & 2 & 3 & $0 \%$ & $1 \%$ & $1 \%$ & $2 \%$ \\
\hline Natural Vegetation & 21 & 6 & 7 & 10 & $11 \%$ & $8 \%$ & $6 \%$ & $4 \%$ \\
\hline Recreational Area & 0 & 0 & 1 & 3 & $0 \%$ & $0 \%$ & $1 \%$ & $2 \%$ \\
\hline Road & 2 & 5 & 4 & 6 & $1 \%$ & $2 \%$ & $3 \%$ & $4 \%$ \\
\hline Rock Area & 13 & 13 & 13 & 12 & $7 \%$ & $7 \%$ & $7 \%$ & $7 \%$ \\
\hline Settlement & 4 & 36 & 43 & 46 & $2 \%$ & $15 \%$ & $21 \%$ & $26 \%$ \\
\hline Water & 3 & 2 & 2 & 1 & $2 \%$ & $1.1 \%$ & $0.8 \%$ & $0.6 \%$ \\
\hline
\end{tabular}

\section{Developments over the Last Two Decades}

The last two decades witnessed fasten growth across the study area in terms of the establishment of industries [7] and attract other upcoming projects of IT parks as well. It blooms the export potential of the Gurgaon districts and generates employment for the villagers across the area. The Gurgaon-Manesar-Bawal belt [3] has emerged as the auto hub and there are various industrial production units [7] for automobiles, pharmaceutical, software, telecommunications, food processing, insecticide, pesticide, etc. The Government has also planned to connect the Gurgaon city with Manesar via Metro rail Network [3]. The study area also witnessed haphazard development of real estate (Construction area) which does not abide as per the local laws. A well-developed transportation network (4\% of the total area) has resulted in the rapid development of infrastructure projects which also attracts many real estate players in the vicinity. Currently, the construction area of ongoing various projects (other than the already established area) is $6 \%$ of the total study area.

\section{Agriculture}

The Study suggests that the soil of Manesar tehsil area is fertile (loose soil, sandy to sandy-loam) and suitable for agriculture. The crops grown in the study area are divided into two main categories viz. kharif and rabi, locally called as sawani (during Summer) and sadhi (during Winter). The major kharif crops of the study area include paddy, Sorghum, Milletswhile the minor ones include kharif oilseeds, kharif pulses like massar and kharif vegetables (Pumpkin, bitter gourd, okra, cucumber chillies, tomato, brinjal, onion).The major rabi crops are wheat, barley, rapeseed \& mustard oil seeds while the minor ones include rabi pulses, fodder crops, and rabi vegetables (radish, carrot, turnip, brinjal, cauliflower, potato, pea, tomato, Cabbage, palak, methi). Vegetables are main cash crops for the villagers across the study area

However, the acquisition of land by the government on various upcoming and ongoing projects has changed the agricultural pattern of the area. Temporal analysis of satellite imagery [6] suggests that less than 50\% of the land across the tehsil area is utilised for agricultural activity. It also suggests Natural vegetation across the tehsil was $11 \%$ of the total area in the year 1987 which is now fallen to $4 \%$ in 2019. The livelihood of villagers has also impacted significantly. Various Farmers across the study area have lost their farming land due to land acquisition and thus forced to opt alternative sources of income. This includes the rental income of the houses constructed on the agricultural area as well as the amount received from the government as a one-time cost of the acquired land.

\section{Sources of Water}

There is no perennial river across the study area. There are few inland seasonal streams that are smaller in size and does not have much impact on fulfilling increasing water demand [4]. The average rainfall across the area is less and occurs in 
the month of July - Sep. As per data published by the Metrological department the average rainfall during the year 2018 across the Gurgaon district [3] in the month of July was $118.3 \mathrm{~mm}$, August $116 \mathrm{~mm}$ and in the month of September it was $112.2 \mathrm{~mm}$. The average rainfall recorded in past years is less than the required for healthy agricultural activity and sustainable development across the study area.

Manesar area has a dependency on groundwater [4] for agriculture as well as daily needs. Interpretation of past satellite imagery [6] suggests that the natural water sources(canals) have been reduced to $0.6 \%$ of the total area due to drying natural pond, encroachments of canals, and rapid construction. The study suggests that the Unsustainable development of the area has increased water demand and decreasing rainfall results in over-exploitation of groundwater to meet the daily need of the residents as well as for agriculture. Groundwater \& surface water from Gurgaon Water [4] Supply (GWS) canal are the sources for water supply in Manesar. The village across the Manesar tehsil is also dependent upon the groundwater for agricultural purposes. As per the report published by the Central Ground Water Board the water table [4] in the Gurgaon district is getting depleted by $1-1.2$ Meters every year. This may go worsen in the study area due to haphazard development, high population density and thus increasing the high demand for water.

\section{CONCLUSIONS AND RECOMMENDATION}

Manesar Township as well as other villages across the tehsil is going to be spatially expanded soon. Increasing Population density will result in high water demand. Currently, the dependency is on groundwater which may worsen in the coming days as CGWB has reported the depletion of the water table by 1-1.2 meter every year. There were also various haphazard developments, construction of real estate buildings not meeting the criteria of a planned city. These developments may lead to increasing environmental problems in the coming days in terms of Solid waste management, poor drainage, waterlogging [4], etc. The Manesar town area always faces the danger of flooding due to proximity to the southern hills. During the rainy season, the runoff from the hills can cause several issues. The concerned authority must be stricter bylaws on all construction activities. Currently, more than 150,000 people (Equivalent to the population of residents) are daily visiting the Manesar area who is working across various industries [7]. Integrated use of transport, like mass transit system (Metro rail, Monorail, Public buses) may reduce the increasing population density [10] of migrants getting settled in Manesar and help the people to travel from various NCR regions. Compulsory Livelihood training for farmers who sacrificed their land for development across Government projects must be initiated. The government in partnership with the companies under CSR (Company social responsibility) activity should spread awareness among the villagers for organic farming, horticulture, sericulture, etc. The lesson learned from failure in planning the Gurgaon city area must be taken into consideration and Coordination among various government organizations must be balanced for the speedy resolution of open issues and faster decision-making. This may lead to a path toward strengthening governance. The guidelines to obtain various permission across the government machinery must be updated to accommodate the various new planning strategies. A public-private partnership may be the best approach where faster development may occur with world-class a amenity which is currently lacking to a greater extent.

\section{ACKNOWLEDGEMENT}

The authors are grateful to the Amity Institute of Geo informatics and Remote Sensing (AIGIRS), Amity University, NOIDA, UP, India, for the GIS-based analysis. 
Manuj Dev: Conceptualization, Methodology, Investigation, Soft-ware, Writing - original draft, Writing - review \& editing. Dr S. M. Veerabhadrappa: Supervision, Writing - Methodology, original draft, Manas Kumar Jha: Methodology, Writing - original draft, Writing -review \& editing

\section{REFERENCES}

\section{Journal Article}

1. Suzanchi, K., \& Kaur, R. (2011). Land use land cover change in National Capital Region of India: A remote sensing \& GIS based two decadal spatial-temporal analyses. Procedia - Social and Behavioral Sciences, 21, 212-221. doi: 10.1016/j.sbspro.2011.07.044

2. Tufa, Damtew Fufa, Yerramsetty. Abbulu, and G. V. R. Srinivasarao. "Watershed hydrological response to changes in land use/land covers patterns of river basin: A review." International Journal of Civil, Structural, Environmental and Infrastructure Engineering Research and Development 4 (2014): 157-170.

3. Jain, M., Dawa, D., Mehta, R., Dimri, A. P., \& Pandit, M. K. (2016). Monitoring land use change and its drivers in Delhi, India using multi-temporal satellite data. Modeling Earth Systems and Environment, 2(1). doi:10.1007/s40808-016-0075-0

4. Siwana, Homendera, A K Koshta, and Hulas Pathak. "Dynamics of Land Use Pattern in Bastar Plateau of Chhattisgarh: A Temporal and Spatial Analysis." International Journal of Agricultural Science and Research (IJASR) 8. 4, Aug 2018, 43-48

5. R. K. Jain, Dr. Kamal Jain, Dr. S. Rehan Ali "Remote Sensing Enabled Urban Growth Analysis for Gurgaon from 1995 To 2015" Advances in Computational Sciences and Technology, ISSN 0973-6107 Volume 10, Number 6 (2017) pp. 1745-1757

6. Pranav N. Desai" Gurgaon-Manesar Urban Complex Challenges of Water Governance "Policy Brief No. 1/2018, Transdisciplinary Research Cluster on Sustainability Studies Jawaharlal Nehru University, New Delhi

7. Shwetha, G., et al. "Estimation of surface runoff in timmapur watershed using SCS-CN method." Int J Agric Sci Res 5.6 (2015): 1-8.

8. Ar. Manoj Panwar, Er. Pardeep Sindhu, Critical Analysis of Land Use Planning along Kundli Manesar Palwal Expressway, International Journal of Latest Trends in Engineering and Technology (IJLTET), Vol.6 Issue 3 January 2016, ISSN:2278$621 X$

9. Mrs. Rupali P Zope, The Planning Strategies for Urban Land Use Pattern: A Case Study of Pune City, India, International Journal of Innovative Research in Science, Engineering and Technology Vol. 2, Issue 7, July 2013

10. Ratnaraju, Ch, et al. "Modelling of infiltration rate of red soil under different land use conditions." International Journal of Agricultural Science and Research (IJASR) 5.5 (2015): 305-312.

11. Dr. Balwan Singh, Role of Smart Cities in Urbanization of Haryana: A Case Study, 2018 IJSRSET|Volume 4|Issue 1| Print ISSN: 2395-1990| Online ISSN: 2394-4099

12. Anuj Tiwari, Merugu Suresh, Arun Kumar Rai, 2014,"Ecological Planning for Sustainable Development with a Green Technology: GIS." International Journal of Advanced Research in Computer Engineering \& Technology (IJARCET) Volume 3 Issue 3

13. Shruti Rajagopalan and Alexander Tabarrok "Lessons from Gurgaon, India's Private City "George Mason University Department of Economics Working Paper No. 14-32

14. Amini Parsa, V., Yavari, A., \& Nejadi, A. (2016). Spatio-temporal analysis of land uselland cover pattern changes in Arasbaran Biosphere Reserve: Iran. Modeling Earth Systems and Environment, 2(4), 1-13. doi:10.1007/s40808-016-0227-2 
Book

15. District Census Handbook-Gurgaon, “Census of India,” New Delhi, 1991, www.censusindia. net

16. District Census Handbook-Gurgaon, “Census of India,” New Delhi, 2001, www.censusindia. Net

17. District Census Handbook-Gurgaon, “Census of India,” New Delhi, 2011, www.censusindia. net

18. Draft Initial Environmental Examination, IND: National Capital Region Urban Infrastructure Financing Facility Tranche 2 IMT Manesar Water Supply Project Prepared by the National Capital Regional Planning Board for the Asian Development Bank - October 2014

\section{REFERENCES}

19. W. Bartz (2001). Ecological and Environmental Aspects of Cutting Fluids. Lubrication Engineering. 57: 13-16.

20. P.S Sreejith and B.K.A Ngoi (2000). Dry machining; Machining of the future. Journal of Materials Processing Technology. 101: $287-291$.

21. T.F Glenn and F Van Antwerpen (1998). Opportunities and market trends in metal working fluids. Lubrication Engineering. 54: $31-37$.

22. S.B. Adejuyigbe, and S.P. Ayodeji, (2000). Soya bean Oil as an Alternative to Soluble Oil in Machining a Mild Steel Material. Nigeria Journal of Pure and Applied Physics. 1: 18-24.

23. S.A., Lawal, I.A Choudhury,.and Y. Nukman, (2011). Application of vegetable oil-based metal working fluids in machining ferrous metals-A review. International Journal of Machine Tools and Manufacture. 52: 1-12.

24. P.A.O., Adegbuyi, G., Lawal, O. Oluseye, and G. Odunaiya, (2010). Analysing the effect of Cutting Fluids on the Mechanical Properties of Mild Steel in a Turning Operation. American Journal of Scientific and IndustrialResearch. 2 (1): 1-10.

25. J.A. Akpobi, and W.O., Enabulele, (2002).Formulation of a water-soluble oil as a metal cuttingfluid, Nig. Inst. of Production Engineers Technical Transactions, Special Edition, 7(3),97-106.

26. R.F Avila and Abrao A.M. (2001). The effect of cutting fluids on the machining of hardened AISI 4340 steel. J. Mater. Process. Technol. 119: 21-26.

27. W.A.J. Chapman (1972). Workshop Technology. Edward Arnold Publishers Limited, U.K. 1:167 -191

28. E.P., DeGarmo, J.T., Black, R.A. Kosher(1984). Materials and Processes in Manufacturing. Maxwell MacMillan Publication, (7th Edition) New York, USA. 578-581.

29. M.M.A., Khan, M.A.H.,Mithu, N.R.Dhar (2009). Effects of minimum quantity lubrication on turning AISI 9310 alloy steel using vegetable oil-based cutting fluid. J. Mater. Process. Technol. 209: 5573-5583.

30. P. Krishna Vamsi, R.R., Srikant, D. Rao (2010). Experimental investigation on the performance of nanoboric acid suspensions in SAE-40 and coconut oil during turning of AISI 1040 steel. Int. J. Mach. Tool Manuf. 50: 911-916.

31. E., Kuram,B., Ozcelik, E.,Demirbas,E. Sik (2010). Effects of the cutting fluid types and cutting parameters on surface roughness and thrust force. Proceedings of the WCE 2010, London, UK. Vol. II, June 30-July 2, 2010.

32. S.A., Lawal,M.S., AbolarinB.I., Ugheoke,E.O Onche (2007). Performance evaluation of cutting fluids developed from fixed oils. LEJPT 10: 137-144.

33. A.W.C, Menzies, W.Q, Kleinspehn, G.Q Lewis, and E.C Bingham (1922). Determination of specific heat, density, surface tension, viscosity and lubricating values of typical oils. National Bureau of Standards, U.S.A. 16:55-64 
34. S., Sharif, N.M., Yusof,M.H., Idris,Z.B., Ahmad,I., Sudin,A., Ripinand M.A.H. Mat Zin (2009). Feasibility study of using vegetable oil as a cutting lubricant through the use of minimum quantity lubrication during machining. Research VOT No. 78055, Department of Manufacturing and Industrial Engineering, Faculty of Mechanical Engineering, UniversitiTeknologi Malaysia. http://eprints.utm.my/9729/1/78055.pdfS. 

